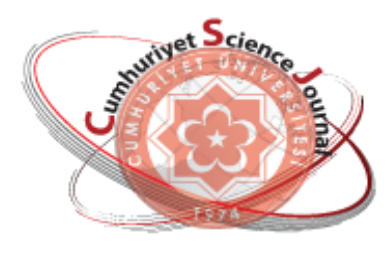

e-ISSN: 2587-246X

ISSN: $2587-2680$

\section{Cumburisy at Seionee Journal $\operatorname{csg}$}

Cumhuriyet Sci. J., Vol.39-3(2018) 621-627

\title{
Altitude Triggers Some Biochemical Adaptations of Polygonum cognatum Meissn. Plants
}

\author{
Oksal MACAR*, Tuğçe KALEFETOĞLU MACAR \\ Giresun University, Şebinkarahisar School of Applied Sciences, Department of Food Technology, Giresun, \\ TURKEY
}

Received: 04.01.2018; Accepted: 11.06.2018

http://dx.doi.org/10.17776/csj.375050

\begin{abstract}
Madimak is a local name of Polygonum cognatum which is known as a nutrient- and phenolic-rich edible plant in Turkish traditional cuisine. Knotweed (madimak) is usually found in both agricultural and nonagricultural areas at different altitudes from 720 to 3000 meters. This study aimed to investigate some biochemical effects of altitude in knotweed plants. Knotweed leaf samples collected from two different elevations (1656 and 1170 meters) of mountainous regions of Şebinkarahisar (Giresun, Turkey) at optimum vegetation stage. The total chlorophyll and carotenoid levels were determined in fresh leaves while the total flavonoid amount, proline and the total soluble sugar contents in dried leaf samples spectrophotometrically. The proline and the total flavonoid contents were more abundant whereas the amounts of soluble sugars, the total chlorophyll and carotenoids decreased at higher altitude plants. Altitudinal gradient affects the important parameters in the biochemistry of knotweed. Especially, owing to the flavonoid-rich content, higher located knotweed could be defined as a functional food.
\end{abstract}

Keywords: Altitude, Flavonoid, Polygonum cognatum, Photosynthetic pigment, Proline, Soluble sugar.

\section{İrtifa Polygonum cognatum Meissn. Bitkilerindeki Bazı Biyokimyasal Değişiklikleri Tetiklemektedir}

\begin{abstract}
Özet. Geleneksel Türk mutfağında besin maddesi ve fenolik madde bakımından zengin bir bitki olarak bilinen Polygonum cognatum'un yerel ismi madımaktır. Madımak genellikle hem tarımsal hem de tarımsal olmayan alanlarda 720'den 3000 metreye kadar değişen yüksekliklerde bulunur. Bu çalışma irtifanın madımak bitkileri üzerindeki bazı biyokimyasal etkilerini araştırmayı amaçlamıştır. Madımak yaprak örnekleri optimum vejetasyon döneminde Şebinkarahisar'ın (Giresun, Türkiye) dağlık bölgelerindeki 2 farklı irtifadan (1656 ve 1170 metre) toplanmıştır. Toplam klorofil ve karotenoid seviyeleri taze yapraklarda; toplam flavonoid miktarı, prolin ve toplam çözünebilir şeker içerikleri ise kuru yaprak örneklerinde spektrofotometrik olarak analiz edilmiştir. Yüksek irtifa bitkilerindeki prolin ve toplam flavonoid içerikleri daha fazla iken; çözülebilir şeker, toplam klorofil ve karotenoidler azalmıştır. İrtifa değişimi madımağın biyokimyasında önemli parametreleri etkilemektedir. Özellikle, flavonoid bakımından zengin içeriği sayesinde, yüksek irtifada bulunan madımak bir fonksiyonel gıda olarak tanımlanabilir.
\end{abstract}

Anahtar Kelimeler: Çözünebilir şeker, Flavonoid, Fotosentetik pigment, İrtifa, Polygonum cognatum, Prolin.

\section{INTRODUCTION}

High elevation plants have to overcome some adverse conditions such as reduced atmospheric pressure, low temperature, strong wind, brief season length and high UV light intensity [1]. Since plants are sessile organisms, these powerful "natural forces" compel plants to develop some decisive traits. The survival of plants in extreme conditions depends on their physiological adaptations to different stress factors [2]. It may be 
generalized that the same plant species are known to exhibit different protective mechanisms at higher elevations.

In a number of plant species, light intensity, photoperiod and temperature influence the biosynthesis of many secondary metabolites such as plant phenolics [3]. Close and McArthur suggest that the main role of plant phenolics may protect leaves from photodamage by acting as antioxidants [4]. Flavonoids, the vast class of phenolic metabolites, are nearly ubiquitous in plants. They are recognized as the low molecular weight compounds and have long been reported as having the functional services in plants suffering from a lot of environmental damages [5,6]. Besides playing multiple biological roles in plant defence mechanisms, such as absorption of the excessive ultraviolet radiation, prevention of reactive oxygen species (ROS) generation and quenching of the ROS, they possess beneficial antioxidant potentials for human health [3, 7].

Plants grown at high altitudes may avoid damages caused by freezing or ice crystallization by increasing the number of solutes such as proline and soluble sugars in their tissues [8]. Proline and soluble sugars are recognized as compatible osmolytes that regulate water balance along with quenching ROS during stressful conditions $[9,10]$. Accumulation of these compounds in different parts of plants increases in response to the variety of harsh environmental circumstances [11]. Aside from mitigating the adverse effects of stress factors in plants, they are crucial parts of dietary requirements for human health.

Plants that exposed to the higher light intensities and lower mean temperatures at increased altitudes may be at risk of photodestruction. Carotenoids, as an important part of the photosynthetic machinery, are well known to play significant roles in the photoprotection of chloroplastic membranes against the excessive amounts of solar energy absorbed by photosynthetic pigments [12]. Increased carotenoid levels at high altitudes could be suggested that those pigments act as security valves releasing the extreme PAR (photosynthetically active radiation) energy against any risk of photodestruction. However, some studies have shown that lower photosynthetic pigment amount is one of the trends observed at increasing altitudes $[13,14]$.

Turkey is regarded as one of the richest countries in the world in terms of plant biodiversity with over
9000 plant species [15] due to its geographical location and climate factors. People are increasingly concerned about the nutritional value of the foods they consume and green leafy vegetables are important parts of a healthy diet [16]. Many wild edible plants are traditionally used in human nutrition and consumed as a vegetable in Turkey [17]. In addition, a great deal of wild plants collected for medical purposes by locally in various regions of Turkey. In general, wild edible plants are good and cheap sources of proteins, vitamins, minerals, essential fatty acids, carbohydrates, fibers, antioxidants secondary metabolites, phenolic compounds [18]. All these contents make these plants precious supplements for healthy diets in even the most developed countries [19,20]. Knotweed (Polygonum cognatum Meissn.) is a perennial herb called 'madimak' in Turkish which plays a significant role in conventional diets in Turkey. This edible wild plant grows on roadsides, slopes and cliffs at 720-3000 m altitudes [21]. In traditional Turkish cuisine, the fresh leaves and the stem of the knotweed are valuable foods with rich antioxidant and antimicrobial contents. Knotweed has a broad altitudinal tolerance. Due to its frequent usage as a vegetable and a folkloric medicinal plant $[21,22]$, it is important to research the effects of natural habitat with different altitudes on biochemical parameters.

The present work was carried out to investigate the effects of elevation gradient on knotweed plants by comparing the total flavonoid content, the total chlorophyll and carotenoid pigment levels, proline and soluble sugar amounts of plants that were harvested at different elevations.

\section{MATERIALS AND METHODS}

Some physiological properties of the knotweed were evaluated. Plant samples were harvested at elevations of $1656\left(40^{\circ} 18^{\prime} 11^{\prime \prime} \mathrm{N}\right.$ latitude and $38^{\circ} 23^{\prime} 11^{\prime \prime}$ E longitude) and $1170\left(40^{\circ} 15^{\prime} 08^{\prime \prime} \mathrm{N}\right.$ latitude and $38^{\circ} 24^{\prime} 45^{\prime \prime}$ E longitude) meters from mountainous regions of Şebinkarahisar (Giresun, Turkey) in May 2017 at the optimum growth stage of the plant for consumption. Taxonomic identifications of the plants were performed by Assoc. Prof. Dr. Zafer TURKMEN, University of Giresun, Faculty of Science and Literature, Department of Biology.The experiments were carried out with two sets of samples obtained from two different sub-districts (1656 and 1170 meters altitudes). Locations had similar ecological characteristics (soil, direction, slope degree etc.) 
except elevation. Samples collected from three randomly selected points (more than 50 meters apart). Fresh leaves were used to determine the total chlorophyll and the total carotenoid levels while the total contents of flavonoids, proline and soluble sugars were analyzed in dry grounded leaf samples. Edible parts of the plant were cut and dried in laboratory conditions. Dried samples were ground by using a blender and kept in a refrigerator until analysis.

To determine the photosynthetic pigment content of leaves, freshly weighted leaf segments from each of the three replicates were used. Total chlorophylls $(a+b)$ and total carotenoids $(x+c)$ were extracted from leaves in $1 \mathrm{ml}$ of $100 \%$ acetone. The absorbance of extracts was measured at $470,644.8$ and $661.6 \mathrm{~nm}$, using a Shimadzu Mini-1240 UV-Vis spectrophotometer. The content of chlorophylls $(a+b)$ and carotenoids $(x+c)$ were calculated using adjusted extinction coefficients [23]. The contents of both pigment types are expressed as $\mathrm{mg} \mathrm{g} \mathrm{FW}^{-1}$.

The free proline contents of high and low elevation plant samples were determined using the method of Bates et al. [24]. Proline was extracted from dried leaf samples (20 mg DW) of each replicate according to Weimberg with minor modifications [25]. Following the addition of acid ninhydrin and glacial acetic acid, the mixture prepared with homogenized leaves was heated for $1 \mathrm{~h}$ in a boiling water bath. Ice bath was used to stop the reaction. The mixture was then extracted with toluene and the chromophore containing toluene was separated from the aqueous phase. The absorbance of the fraction containing toluene was monitored at $520 \mathrm{~nm}$ using toluene for a blank. Proline concentration ( $\left.\mu \mathrm{mol} \mathrm{g}{ }^{-1} \mathrm{DW}\right)$ was determined by calculations based on a proline standard curve.

The total flavonoid content of each replicate was evaluated by following the method involving aluminium chloride colorimetry mentioned previously by Marinova et al. with slight modifications [26]. Flavonoid constituents were extracted from 48 hours dried leaf samples with 50 $\mathrm{ml} 80 \%$ aqueous methanol and were sonicated for $20 \mathrm{~min}$. An aliquot of the methanolic extracts was centrifuged for $5 \mathrm{~min}$ at $14000 \mathrm{rpm}$. $1 \mathrm{ml}$ extract was added to a flask containing $4 \mathrm{ml}$ distilled deionized water. $0.3 \mathrm{ml} 5 \% \mathrm{NaNO}_{2}$ solution was added to the flask and the flask was vortexed. After standing for $5 \mathrm{~min}$, the mixture combined with 0.3 $\mathrm{ml} 10 \% \mathrm{AlCl}_{3}$ solution. $2 \mathrm{ml} 1 \mathrm{M} \mathrm{NaOH}$ was added and the total volume was made up to $10 \mathrm{ml}$ with $\mathrm{dd}$ $\mathrm{H}_{2} \mathrm{O} 5$ min later. The solution was then mixed. Then the maximum absorbance of the reaction mixture was read against a reagent blank containing dd $\mathrm{H}_{2} \mathrm{O}$ instead of the extract at $510 \mathrm{~nm}$ with a (UV mini 1240 Shimadzu) spectrophotometer. All the preparations were performed at room temperature and all samples were analyzed in triplicates. A standard curve was achieved by using the absorbances of catechin in the $20-100 \mathrm{mg} / \mathrm{l}$ concentrations at $510 \mathrm{~nm}$. The total flavonoid contents of the leaves were expressed as $\mathrm{mg}$ catechin equivalents $((\mathrm{CE}) / 100 \mathrm{~g}$ of extract).

The total soluble sugar amount of dried leaves was measured by anthrone colorimetric assay according to Yemm and Willis with some modifications [27]. The anthrone reagent was prepared freshly by dissolving $1 \mathrm{~g}$ anthrone in $500 \mathrm{ml}$ of $72 \% \mathrm{H}_{2} \mathrm{SO}_{4}$ solution and kept at room temperature until it was clear. The total soluble sugars were extracted from $0.1 \mathrm{~g}$ ground leaf samples with aliquots of $80 \%$ ethanol. The solution was filtered to obtain the supernatant for soluble sugar assay. $5 \mathrm{ml}$ anthrone reagent was pipetted to $1 \mathrm{ml}$ of ice-cooled extract material. The mixture was then boiled for 10 minutes in a water bath and cooled on ice for 5 minutes. Following the measurement of absorbance at $630 \mathrm{~nm}$ against distilled $\mathrm{H}_{2} \mathrm{O}$ as a reagent blank, the total soluble sugar content was calculated from a standard curve made using glucose and expressed as $\mu \mathrm{mol} / \mathrm{g}$ dry weight.

Means obtained from all analysis were given in figures with error bars which stand for standard errors. Statistical significance of the means was analyzed by SPSS 23 software. Values at $\mathrm{P}<0.05$ were considered to be significant.

\section{RESULTS AND DISCUSSION}

Challenging factors at increasing altitudes enforce plants to improve some adaptations which let plants survive. One of the best-characterized adaptation mechanisms in plants at higher elevations is the accumulation of osmoprotectants. Proline, a well-known osmoprotectant and an essential signal molecule in stress responses, was found to be nearly two times higher at higher altitude madimak leaves (Fig. 1). Öncel et al. reported that elevated proline contents have a very important role in the stress resistance of the alpine plants [28]. A further rise in proline content of 
plants at high mountains may be a part of the tolerance mechanism against cold, wind and other high altitude related stresses.

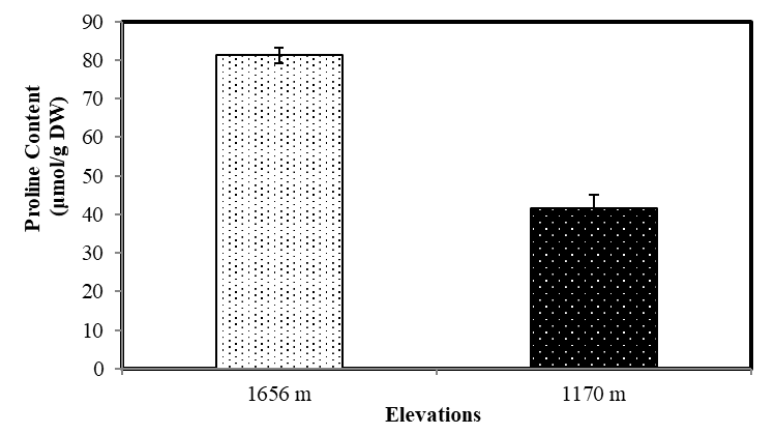

Figure 1. Proline contents at high and low altitude located knotweed leaves.

In traditional Turkish cuisine, the green parts of the Polygonum cognatum Meissn. are valuable foods with rich antioxidant contents. Flavonoids are among these antioxidant compounds in plants and are famous for their radical-scavenging effects [29]. Additionally, the accumulation of flavonoids in the vacuoles of epidermal tissues in a number of plants weakens the UV components of sunlight and minimalizes the excess absorption of PAR [30]. In our study, the leaves of higher location plants are more abundant in the total flavonoid levels (Fig. 2). The elevated total flavonoid contents at high altitude madimak leaves verified the fact that flavonoid synthesis is induced by UV-light [31]. This UV-mediated flavonoid response is one of the crucial reactions of irradiated leaves at highlocated plants.

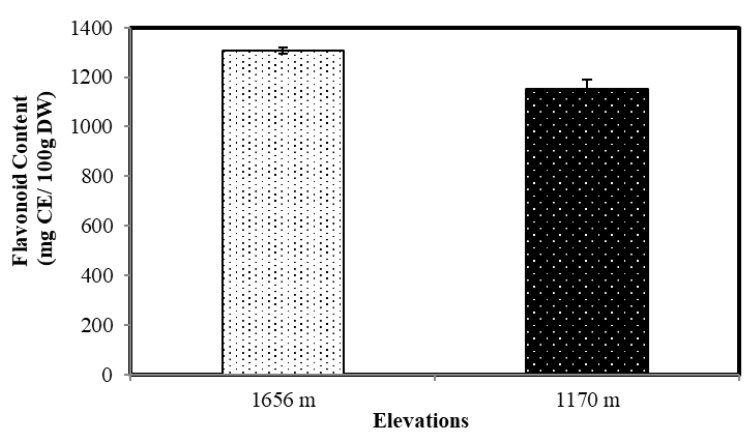

Figure 2. Total flavonoid contents at high and low altitude located knotweed leaves.

The photosynthetic apparatus of high altitude plants may be a sensitive target of UV-B radiation due to reduced photosynthetic and accessory pigments [32]. In our study, there is a striking reduction of chlorophyll and carotenoid pigment levels at high altitude located madimak leaves (Fig. 3 and Fig. 4) although the marked rises of proline and flavonoid levels. Proline accumulation at higher altitudes is a well-known protection mechanism to prevent harmful effects originated from photodestruction via minimizing the membrane damages [33]. However, some studies have shown that altitudinal stress leads to increased proline synthesis along with decreased chlorophyll pigment levels [34].

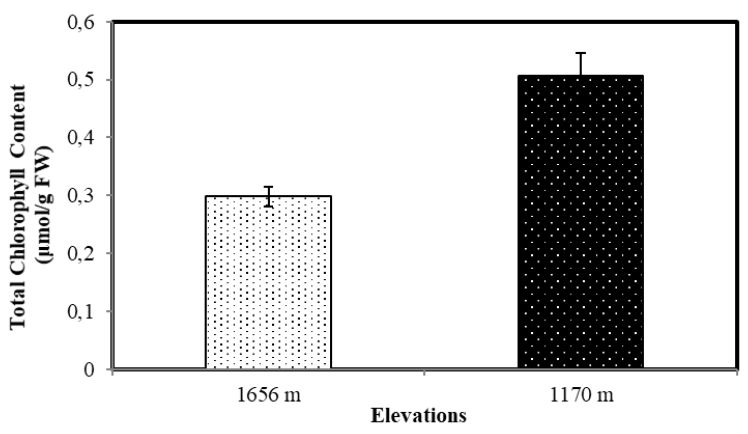

Figure 3. Total chlorophyll contents at high and low altitude located knotweed leaves.

High solar UV-B imposed plants exhibited high accumulations of both proline and photoprotective pigments [35]. Also it was shown that exogenous proline raised the chlorophyll contents and net photosynthetic rate of some stressed plants [36]. Induced protection mechanisms may be insufficient to block the damages to the photosynthetic and accessory pigments against stress factors arose from high altitudes. Inadequate amount of carotenoids to safely dissipate excess energy by xanthophyll cycle in high altitude madimak leaves are possibly the main suspects of decreased chlorophyll contents.

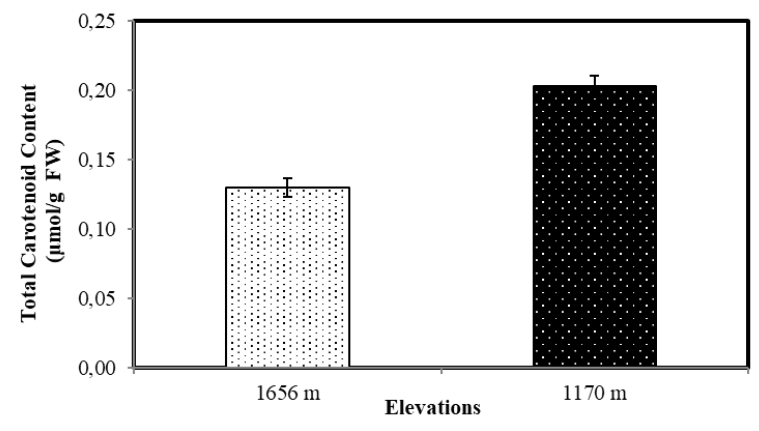

Figure 4. Total carotenoid contents at high and low altitude located knotweed leaves. 
A sharp decline in photosynthetic pigment amounts led a slight drop in the soluble sugar contents (Fig. $5)$.

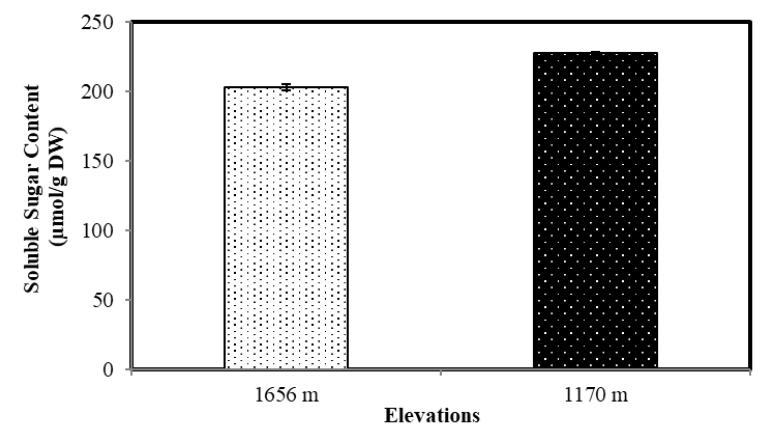

Figure 5. Soluble sugar contents at high and low altitude located knotweed leaves.

Soluble sugars have vital roles in plant structure and metabolism. Besides being important nutrients, they act as signaling molecules to activate stressinduced pathways against extreme conditions, thus resulting in important modifications of gene expression [37]. In some studies, at high altitudes, increased sugar accumulations were accompanied by ascended proline biosynthesis [38]. Plants also tend to protect themselves against cold-related osmotic stresses via the accumulation of these organic solutes. Despite the soluble sugars provide a number of advantages to plants at higher altitudes, the reduced chlorophyll content may be related to the drop in usage of solar energy in photosynthesis. As a result, soluble sugar levels decreased.

The data of this study clearly showed that altitudinal gradient modifies the important parameters in plant physiology and biochemistry. According to the results, it may be suggested that the combined effects of limiting conditions like lower temperature, strong wind and higher UV intensity at higher habitats force plants to improve some adaptations. Proline and flavonoid contents were significantly risen at $1656 \mathrm{~m}$ altitude to defend the plants against stress factors mentioned above. However, our results indicated that these protectants were insufficient to protect photosynthetic pigments completely from solar UV-B damage. Due to damaged photosynthetic pigments, net photosynthetic rate and total sugar contents in high elevation were reduced. Although the slight drop in the total soluble sugar contents at higher altitude located plants, the flavonoid-rich leaves of both plants indicate that these weeds could be potential sources of natural antioxidant compounds. There are many choices of functional food sources and this work contains valuable clues for further studies about nutritive values and potential uses of wild edible plants.

\section{REFERENCES}

[1]. Korner C, Diemer M. In situ photosynthetic responses to light, temperature and carbon dioxide in herbaceous plants from low and high altitude. Funct Ecol. 1(3) (1987) 179194.

[2]. Hasanuzzaman M, Nahar K, Alam MM, Roychowdhury R, Fujita M. Physiological, biochemical, and molecular mechanisms of heat stress tolerance in plants. Int J Mol Sci. 14(5) (2013) 9643-9684.

[3]. Jaakola L, Hohtola A. Effect of latitude on flavonoid biosynthesis in plants. Plant Cell Environ. 33(8) (2010) 1239-1247.

[4]. Close DC, McArthur C. Rethinking the role of many plant phenolics-protection from photodamage not herbivores?. Oikos. 2002; 99(1) (2002) 166-172.

[5]. Brunetti C, Di Ferdinando M, Fini A, Pollastri S, Tattini M. Flavonoids as antioxidants and developmental regulators: relative significance in plants and humans. Int J Mol Sci. 14(2) (2013) 3540-3555.

[6]. Middleton E, Kandaswami C, Theoharides TC. The effects of plant flavonoids on mammalian cells: implications for inflammation, heart disease, and cancer. Pharmacol Rev. 52(4) (2000) 673-751.

[7]. Xing RR, He F, Xiao HL, Duan CQ, Pan QH. Accumulation pattern of flavonoids in Cabernet Sauvignon grapes grown in a lowlatitude and high-altitude region. S Afr J Enol Vitic. 36(1) (2015) 32-43.

[8]. Ma L, Yang L, Zhao J, Wei J, Kong X, Wang $\mathrm{C}$, et al. Comparative proteomic analysis reveals the role of hydrogen sulfide in the adaptation of the alpine plant Lamiophlomis rotata to altitude gradient in the Northern Tibetan Plateau. Planta. 241(4) (2015) 887906.

[9]. Cao YY, Yang, MT, Li X, Zhou ZQ, Wang $\mathrm{XJ}$, Bai JG. Exogenous sucrose increases chilling tolerance in cucumber seedlings by modulating antioxidant enzyme activity and regulating proline and soluble sugar contents. Sci Hortic 179 (2014) 67-77.

[10]. Xi Z, Wang Z, Fang Y, Hu Z, Hu Y, Deng M, Zhang Z. Effects of 24-epibrassinolide 
on antioxidation defense and osmoregulation systems of young grapevines ( $V$. vinifera L.) under chilling stress. Plant Growth Regul. 71(1) (2013) 5765.

[11]. Mohammadkhani N, Heidari R. Droughtinduced accumulation of soluble sugars and proline in two maize varieties. World Appl Sci J. 3(3) (2008) 448-453.

[12]. González JA, Gallardo MG, Boero C, Cruz ML, Prado FE. Altitudinal and seasonal variation of protective and photosynthetic pigments in leaves of the world's highest elevation trees Polylepis tarapacana (Rosaceae). Acta Oecol.32(1) (2007) 36-41.

[13]. Zhang SB, Zhou ZK, Hu H, Xu K, Yan N, $\mathrm{Li}$, SY. Photosynthetic performances of Quercuspannosa vary with altitude in the Hengduan Mountains, Southwest China. For Ecol Manage. 212(1) (2005) 291-301.

[14]. Richardson AD, Berlyn GP. Spectral reflectance and photosynthetic properties of Betula papyrifera (Betulaceae) leaves along an elevational gradient on Mt. Mansfield, Vermont, USA. Am J Bot. 89(1) (2002) 8894.

[15]. Turan M, Kordali S, Zengin H, Dursun A, Sezen Y. Macro and micro mineral content of some wild edible leaves consumed in Eastern Anatolia. Acta Agric Scand B Soil Plant Sci. 53(3) (2003) 129-137.

[16]. Yoon YE, Kuppusamy S, Cho KM, Kim PJ, Kwack YB, Lee YB. Influence of cold stress on contents of soluble sugars, vitamin $\mathrm{C}$ and free amino acids including gammaaminobutyric acid (GABA) in spinach (Spinacia oleracea). Food Chem. 215 (2017) 185-192.

[17]. Kibar B, Kibar H. Determination of the nutritional and seed properties of some wild edible plants consumed as vegetable in the Middle Black Sea Region of Turkey. S Afr J Bot. 108 (2017) 117-125.

[18]. Khan H, Jan SA, Javed M, Shaheen R, Khan $\mathrm{Z}$, Ahmad A, et al. Nutritional composition, antioxidant and antimicrobial activities of selected wild edible plants. J Food Biochem. 40(1) (2016) 61-70.

[19]. Kibar B, Temel S. Evaluation of mineral composition of some wild edible plants growing in the Eastern Anatolia region grasslands of Turkey and consumed as vegetable. J Food Process Preserv. 40(1) (2016) 56-66.
[20]. Jman Redzic S. Wild edible plants and their traditional use in the human nutrition in Bosnia-Herzegovina. Ecol Food Nutr. 45(3) (2006) 189-232.

[21]. Yildırım A, Mavi A, Kara AA. Antioxidant and antimicrobial activities of Polygonum cognatum Meissn extracts. J Sci Food Agric. 83(1) (2003) 64-69.

[22]. Bayrak Özbucak T, Ergen Akçin Ö, Yalçın S. Nutrition contents of the some wild edible plants in Central Black Sea region of Turkey. IJNES. 1 (2007) 11-13.

[23]. Lichtenthaler HK. Chlorophylls and carotenoids: pigments of photosynthetic biomembranes. Meth Enzymol. 148 (1987) 350-382.

[24]. Bates LS, Waldren RP, Teare ID. Rapid determination of free proline for water-stress studies. Plant Soil.39(1) (1973) 205-207.

[25]. Weimberg R. Solute adjustments in leaves of two species of wheat at two different stages of growth in response to salinity. Physiol Plant. 70(3) (1987) 381-388.

[26]. Marinova D, Ribarova F, Atanassova M. Total phenolics and total flavonoids in Bulgarian fruits and vegetables. J Chem Technol Metall.40(3) (2005) 255-260.

[27]. Yemm EW, Willis AJ. The estimation of carbohydrates in plant extracts by anthrone. Biochem J. 57(3) (1954) 508-514.

[28]. Öncel I, Yurdakulol E, Keleş Y, Kurt L, Yildiz A. Role of antioxidant defense system and biochemical adaptation on stress tolerance of high mountain and steppe plants. Acta Oecol. 26(3) (2004) 211-218.

[29]. Nenadis N, Wang LF, Tsimidou M, Zhang HY. Estimation of scavenging activity of phenolic compounds using the ABTS •+ assay. J Agric Food Chem. 52(15) (2004) 4669-4674.

[30]. Casati P, Walbot V. Differential accumulation of maysin and rhamnosylisoorientin in leaves of highaltitude landraces of maize after UV-B exposure. Plant Cell Environ. 28(6) (2005) 788-799.

[31]. Caldwell MM, Robberecht R, Flint SD. Internal filters: prospects for UVacclimation in higher plants. Physiol Plant. 58(3) (1983) 445-450.

[32]. Teramura AH, Sullivan JH. Effects of UV-B radiation on photosynthesis and growth of terrestrial plants. Photosynth Res. 39(3) (1994) 463-473. 
[33]. Unal BT, Guvensen A, Dereboylu AE, Ozturk M. Variations in the proline and total protein contents in Origanum sipyleum L. from different altitudes of spil mountain Turkey. Pak J Bot. 45(1) (2013) 571-576.

[34]. Koç E, İşlek C, Üstün AS. Effect of cold on protein, proline, phenolic compounds and chlorophyll content of two pepper (Capsicum annuum L.) varieties. GUJS. 23(1) (2010) 1-6.

[35]. Berli FJ, Alonso R, Bressan-Smith R, Bottini R. UV-B impairs growth and gas exchange in grapevines grown in high altitude. Physiol Plant. 149(1) (2013) 127-140.
[36]. Yan Z, Guo S, Shu S, Sun J, Tezuka T. Effects of proline on photosynthesis, root reactive oxygen species (ROS) metabolism in two melon cultivars (Cucumis melo L.) under $\mathrm{NaCl}$ stress. Afr J Biotechnol. 10(80) (2011) 18381-18390.

[37]. Couée I, Sulmon C, Gouesbet G, El Amrani A. Involvement of soluble sugars in reactive oxygen species balance and responses to oxidative stress in plants. J Exp Bot. 57(3) (2006) 449-459.

[38]. Bano A, Rehman A, Winiger M. Altitudinal variation in the content of protein, proline, sugar and abscisic acid (ABA) in the alpine herbs from Hunza valley, Pakistan. Pak J Bot. 41(4) (2009) 1593-1602. 